\title{
Winter movements and long-term dispersal of Steller sea lions in the Glacier Bay region of Southeast Alaska
}

\author{
Michael Rehberg ${ }^{1, *}$, Lauri Jemison ${ }^{2}$, Jamie N. Womble ${ }^{3}$, Gregory O'Corry-Crowe ${ }^{4}$ \\ ${ }^{1}$ Division of Wildlife Conservation, Alaska Department of Fish and Game, 525 West 67th Avenue, Anchorage, Alaska 99518, USA \\ ${ }^{2}$ Division of Wildlife Conservation, Alaska Department of Fish and Game, PO Box 1030, Dillingham, Alaska 99576, USA \\ ${ }^{3}$ National Park Service, Glacier Bay Field Station, 3100 National Park Road, Juneau, Alaska 99801, USA \\ ${ }^{4}$ Harbor Branch Oceanographic Institute, Florida Atlantic University, 5600 US 1 North, Fort Pierce, Florida 34946, USA
}

\begin{abstract}
Steller sea lions Eumetopias jubatus in the Glacier Bay region of northern Southeast Alaska experience greater survival and more rapid population growth than sea lions elsewhere in this region. To better understand demographics of sea lions in the region, and to describe the origins and behavior of sea lions and relate these descriptions to previous studies, we studied genetic origins, residency, foraging range, diving behavior, and dispersal of immature sea lions ( $\leq 24 \mathrm{mo}$ of age) captured in Glacier Bay. Fifty-two percent of individuals had maternal origins in the distant $(550 \mathrm{~km})$ endangered western population rather than in the local recovered eastern population. During winter, 5 mo old pups, dependent on their dams for nutrition, remained within Glacier Bay, diving to shallow depths $(\leq 108 \mathrm{~m})$ mainly during daylight, whereas older (17 mo old) juveniles ranged more widely to areas of known seasonal prey aggregations, performing deep $(\geq 241 \mathrm{~m})$ nocturnal dives. Both pups and juveniles remained within the northern portion of Southeast Alaska, in contrast to farther-ranging pup and juvenile sea lions captured elsewhere in Southeast Alaska. Over the long term, females from Glacier Bay remained within this northern area through maturity and were sighted breeding in this area only. Restricted ranging patterns and natal and breeding philopatry by Steller sea lions of both eastern and western distinct population segment origin in the Glacier Bay region reveal that optimal foraging and breeding conditions likely prevail and help explain the recent colonization, increased survival, and rapid population growth of this species in the region.
\end{abstract}

KEY WORDS: Steller sea lions $\cdot$ Alaska $\cdot$ Glacier Bay $\cdot$ Foraging $\cdot$ Eastern distinct population segment $\cdot$ eDPS $\cdot$ Western distinct population segment $\cdot$ wDPS $\cdot$ Prey availability

\section{INTRODUCTION}

Steller sea lions Eumetopias jubatus are distributed along the North Pacific rim from northern Japan to California (Loughlin et al. 1984, Burkanov \& Loughlin 2005) in 2 distinct population segments with a boundary at longitude $144^{\circ} \mathrm{W}$ (Fig. 1): the endangered western distinct population segment (wDPS), north and west of Glacier Bay, and the recently delisted eastern distinct population segment (eDPS),

\footnotetext{
*Corresponding author: michael.rehberg@alaska.gov
}

to the south and east (Hoffman et al. 2006, O'CorryCrowe et al. 2006, National Marine Fisheries Service 2013, Allen \& Angliss 2015). However, genetic analysis of Steller sea lion pups from recently colonized rookeries in northern Southeast Alaska revealed that this region, which includes Glacier Bay, represents a mixing zone between these 2 evolutionarily distinct population segments (O'Corry-Crowe et al. 2014). Thus, the distinct population segment (DPS) of origin for sea lions in this area is not always clear. The non-

(C) The authors, and outside the USA, the US Government 2018. Open Access under Creative Commons by Attribution Licence. Use, distribution and reproduction are unrestricted. Authors and original publication must be credited.

Publisher: Inter-Research · www.int-res.com 


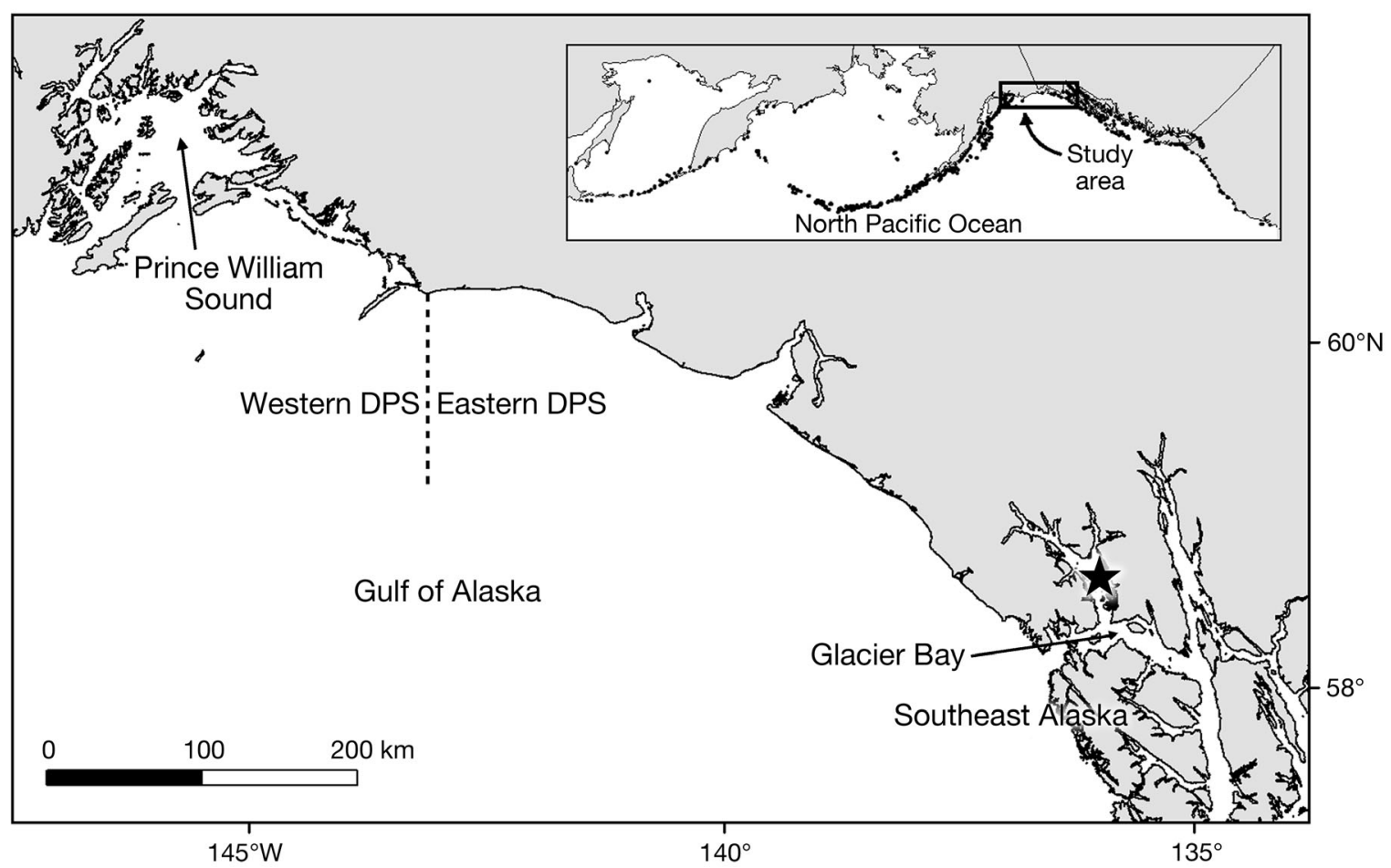

Fig. 1. Study area within which Steller sea lions captured at South Marble Island (indicated by dark star) were tracked by satellite telemetry and by brand-resight observations. Dashed line indicates the geographic boundary between the eastern distinct population segment (DPS) and western DPS. Inset map locates the study area within the range of Steller sea lions (haulouts indicated by dark dots) along the North Pacific rim

neonate Steller sea lions of the Glacier Bay, Icy Strait, and Cross Sound region (hereinafter the Glacier Bay region) have not previously been captured, marked, satellite tracked, or genotyped. The primary objective of this study was to investigate the foraging behavior and dispersal patterns of this relatively unknown subgroup and understand these behaviors in the context of the larger population.

Understanding the movement patterns of Steller sea lions in the Glacier Bay region is important for several reasons. First, unlike sea lions born farther north and south, the Steller sea lions born on and colonizing rookeries in this area near the population boundary are drawn from both the eDPS and wDPS (O'Corry-Crowe et al. 2014), with females born in Prince William Sound having particularly high probabilities of being within this region (Jemison et al. 2013). Second, the sea lion pups in this region have significantly greater survival rates than sea lions elsewhere in Alaska (Hastings et al. 2011, Fritz et al. 2014, Pendleton et al. 2016). Third, the number of sea lions in the Glacier Bay region has increased rapidly compared to elsewhere across the range of Steller sea lions (composite growth of $8.28 \% \mathrm{yr}^{-1}, 1970-2009$; Mathews et al. 2011, Fritz et al. 2014). Fourth, Steller sea lions within the
eDPS, previously listed as threatened under the US Endangered Species Act, were delisted in 2013 (National Marine Fisheries Service 2013); however, the adjacent wDPS remains listed as endangered. Given the occurrence of both eDPS and wDPS sea lions in the Glacier Bay region and the high survival rates recorded for pups in northern Southeast Alaska, investigating the residency patterns, individual movements, diving behavior, and natal dispersal of non-neonate and juvenile Steller sea lions in the Glacier Bay region could provide critical insights into the factors that influence sea lion behavioral ecology, survival, and reproductive success in this transition zone between 2 DPSs with very different population trajectories.

Throughout Southeast Alaska, including the Glacier Bay region, the eDPS of Steller sea lions has grown steadily over the past $30 \mathrm{yr}$ (Pitcher et al. 2007, Mathews et al. 2011). In contrast, over the same time span, the wDPS north and west of Glacier Bay declined by approximately $80 \%$, followed by a geographically uneven recovery in survival and population size since 2003 (Fritz et al. 2014, 2016). The Glacier Bay region contains haulouts (including South Marble Island, established 1985) and breeding rookeries (White Sisters, established early 1990s; Graves 
Rocks, established 1999) colonized more recently than those colonized north of Glacier Bay by the wDPS and south of Glacier Bay by the eDPS (Womble et al. 2009, Mathews et al. 2011, O'Corry-Crowe et al. 2014). The rapid growth in the number of sea lions in the Glacier Bay region is in contrast to the sympatric harbor seal Phoca vitulina which declined precipitously in Glacier Bay from 1992 to 2008 (Mathews \& Pendleton 2006, Womble et al. 2010).

Unlike Steller sea lions studied in other regions of Alaska, non-neonate and yearling Steller sea lions of the Glacier Bay region have not been tracked using satellite telemetry. The objective of this study was to place these relatively unstudied subgroups of sea lions in the context of the larger population. We accomplished this by comparing the behavior of immature Steller sea lions in the Glacier Bay region during the winter of 2009 to 2010 to the behavior of immature sea lions previously studied in other regions of Alaska (Raum-Suryan et al. 2004, Pitcher et al. 2005) and to prey availability in this region. We also compared their age-specific mass with that of Steller sea lions of similar

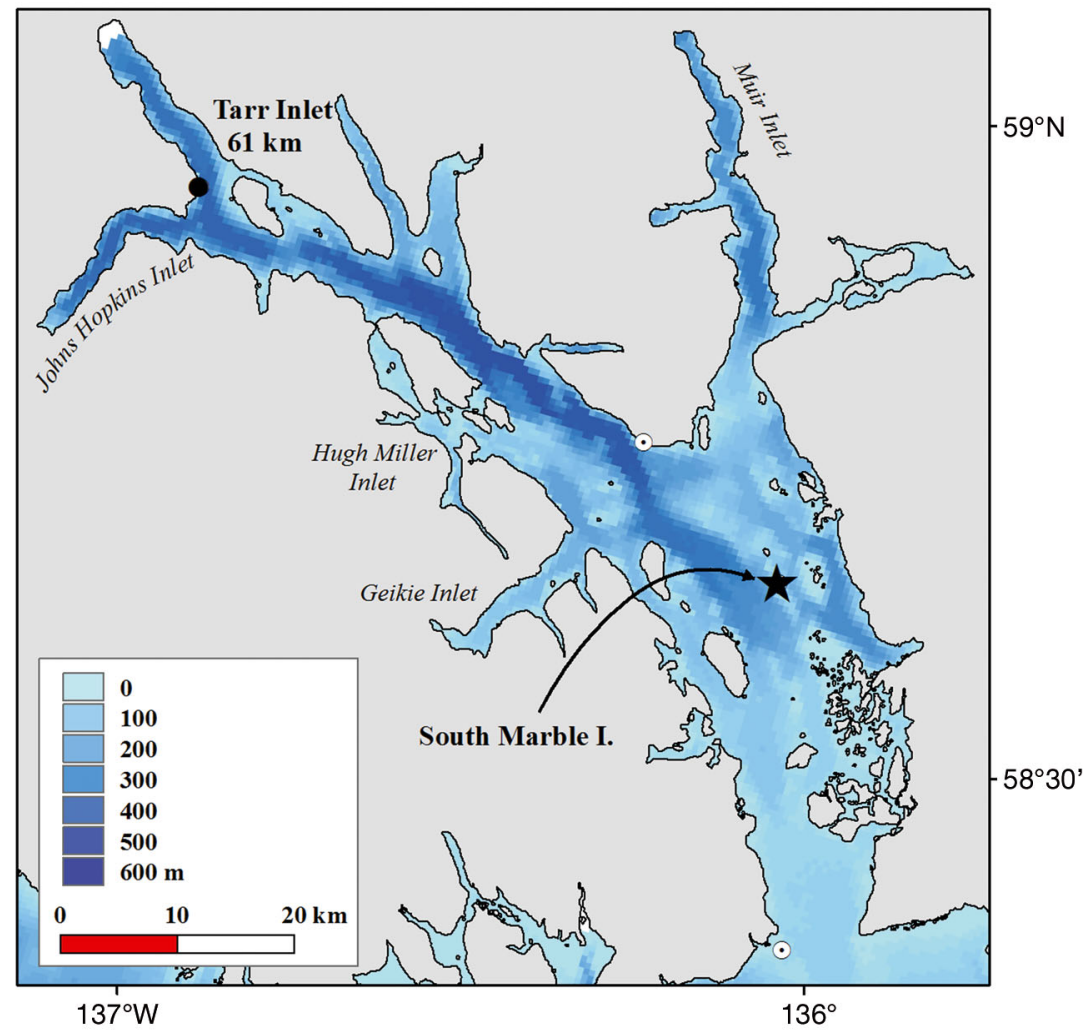

Fig. 2. Range of 5 Steller sea lion pups and 3 juveniles captured and tagged at South Marble Island (indicated by dark star) and moving and diving within Glacier Bay during winter 2009 to 2010. Dark circles indicate haulouts occupied by pups; dotted circles indicate other haulouts available. Shortest path movement distances from the point of capture to each haulout used are indicated adjacent to haulout names. Seafloor depth is indicated by shading and provides context to Table 4 and text

age from other regions. The population origins of these sea lions were identified using analysis of mitochondrial DNA (mtDNA) and placed in context with the genetic origins of Steller sea lions in adjacent areas (O'Corry-Crowe et al. 2014). Finally, natal dispersal movements of captured sea lions were examined to determine where Steller sea lions marked in Glacier Bay settled to breed at maturity.

\section{MATERIALS AND METHODS}

Glacier Bay $\left(58^{\circ} 40^{\prime} \mathrm{N}, 136^{\circ} 05^{\prime} \mathrm{W}\right)$ is a subarctic tidewater glacial fjord in northern Southeast Alaska that has undergone rapid deglaciation over the last 225 yr (Field 1947, Hall et al. 1995; our Fig. 1). Glacier Bay is a marine protected area (MPA) that constitutes part of Glacier Bay National Park, a Biosphere Reserve and World Heritage Site, and includes over 240000 ha of marine waters (National Research Council 2001; our Fig. 2).
Young-of-year Steller sea lion pups (5 mo old) and juveniles (17 mo old) were captured during late autumn, November 2009 (Table 1), at the South Marble Island haulout in central Glacier Bay (Fig. 2), using the underwater dive capture technique (RaumSuryan et al. 2004). Sea lions were then transferred by skiff to a research vessel and placed under isoflurane anesthesia (Heath et al. 1997). Researchers weighed the sea lions using a load cell (IQ Plus 590DC, Rice Lake Weighing Systems) and aged them using canine length (King et al. 2007) assuming 1 June as birthdate (Pitcher et al. 2001). Tissue samples were taken from the hind flippers using a stainless steel ear-notching tool and preserved in $90 \%$ ethanol for genetic analysis. Total DNA was extracted and amplified, and $531 \mathrm{bp}$ of the mtDNA control region were sequenced ( $\mathrm{O}^{\prime}$ Corry-Crowe et al. 2006). Likelihood-based assignment tests (to either the eDPS or wDPS) based on mtDNA haplotype for these newly sampled animals were conducted against previous population baselines calculated for the eDPS 
Table 1. Steller sea lion pups (5 mo old) and juveniles (17 mo old) live captured, marked, sampled, and released at South Marble Island, Glacier Bay, Alaska, during November 2009. Animal identifiers used in this paper are the brand markings applied to each individual. Individual assignments to the eastern or western distinct population segment (DPS) based on mitochondrial DNA (mtDNA) frequencies are indicated; LP indicates statistical power too low to determine, n/a indicates assignment was not possible. Sea lions observed occupying a rookery between 2009 and 2015 are identified by rookery location; sea lions observed breeding at the rookery and year of first reproduction are indicated. Blank entries indicate sea lions were not observed at a rookery and/or breeding. F: female; M: male

\begin{tabular}{|c|c|c|c|c|c|c|}
\hline $\begin{array}{l}\text { Animal } \\
\text { identifier }\end{array}$ & Sex & $\begin{array}{l}\text { Age } \\
(\mathrm{mo})\end{array}$ & $\begin{array}{c}\text { Mass } \\
(\mathrm{kg})\end{array}$ & $\begin{array}{c}\text { mtDNA DPS } \\
\text { assignment }\end{array}$ & $\begin{array}{l}\text { Dispersal to } \\
\text { rookery }\end{array}$ & $\begin{array}{c}\text { Observed } \\
\text { breeding (yr) }\end{array}$ \\
\hline$=716$ & F & 5 & 67.0 & Western & & \\
\hline$=717$ & F & 5 & 54.5 & Western & Graves Rocks & Yes (2014) \\
\hline$=718$ & $\mathrm{~F}$ & 5 & 68.0 & Western & & \\
\hline$=723$ & F & 5 & 55.5 & Eastern & & \\
\hline$=728$ & F & 5 & 73.5 & Western & Graves Rocks & Yes (2015) \\
\hline$=730$ & F & 5 & 64.5 & Eastern & Graves Rocks & Yes (2015) \\
\hline$=732$ & $\mathrm{~F}$ & 5 & 52.5 & Western & Graves Rocks & Yes (2014) \\
\hline$=733$ & F & 5 & 59.0 & Eastern & White Sisters & Yes (2015) \\
\hline$=734$ & F & 5 & 72.5 & $\mathrm{n} / \mathrm{a}$ & Graves Rocks & \\
\hline$=735$ & $\mathrm{~F}$ & 5 & 75.0 & Western & $\begin{array}{r}\text { Graves Rocks/ } \\
\text { White Sisters }\end{array}$ & Yes (2014) \\
\hline$=737$ & F & 5 & 65.0 & Wastern & White Sisters & Yes (2014) \\
\hline$=739$ & $\mathrm{~F}$ & 5 & 52.0 & LP & Graves Rocks & Yes (2014) \\
\hline$=740$ & F & 5 & 66.0 & Western & Graves Rocks & Yes (2015) \\
\hline$=741$ & F & 5 & 71.0 & Western & Graves Rocks & \\
\hline$=743$ & $\mathrm{~F}$ & 5 & 62.5 & Eastern & & \\
\hline$=746$ & F & 5 & 59.0 & $\mathrm{n} / \mathrm{a}$ & White Sisters & Yes (2014) \\
\hline$=721$ & $\mathrm{M}$ & 5 & 89.5 & Western & & \\
\hline$=726$ & $\mathrm{M}$ & 5 & 68.5 & Eastern & & \\
\hline$=729$ & $\mathrm{M}$ & 5 & 63.0 & Eastern & Graves Rocks & \\
\hline$=731$ & $\mathrm{M}$ & 5 & 73.5 & Eastern & & \\
\hline$=736$ & $\mathrm{M}$ & 5 & 73.5 & LP & & \\
\hline$=738$ & $\mathrm{M}$ & 5 & 87.0 & Western & & \\
\hline$=744$ & $\mathrm{M}$ & 5 & 87.0 & Western & Graves Rocks & \\
\hline$=745$ & $\mathrm{M}$ & 5 & 75.5 & Western & & \\
\hline$=7521$ & $\mathrm{~F}$ & 17 & 112.0 & Eastern & White Sisters & Yes (2012) \\
\hline$=727$ & $\mathrm{~F}$ & 17 & 116.0 & LP & White Sisters & \\
\hline$=719$ & $\mathrm{M}$ & 17 & 169.0 & Western & Graves Rocks & \\
\hline$=720$ & $\mathrm{M}$ & 17 & 112.5 & Eastern & & \\
\hline$=722$ & $\mathrm{M}$ & 17 & 141.5 & Eastern & & \\
\hline$=4=$ & $\mathrm{M}$ & 17 & 156.0 & Eastern & Graves Rocks & \\
\hline$=742$ & $\mathrm{M}$ & 17 & 96.0 & $\mathrm{n} / \mathrm{a}$ & & \\
\hline
\end{tabular}

and wDPS (O'Corry-Crowe et al. 2014; see Table 4). To facilitate long-term tracking of movement, survival, and reproduction estimates, sea lions were hot branded on the left shoulder (Hastings et al. 2009) using $0.95 \mathrm{~cm}$ diameter stainless steel irons, forming characters $10.2 \mathrm{~cm}$ high by $7.5 \mathrm{~cm}$ wide.

A subset of pups and juveniles was tracked using satellite-relay dive- and location-reporting instruments (SPLASH Model 201C, Wildlife Computers) attached to the fur using 10 min epoxy (Devcon). Tags were attached to the top of the head of all juveniles and 1 pup; all other pups had tags attached along the dorsal midline between the scapulae (Table 1). Tags were programmed to achieve 8 mo endurance (November through July) at 250 transmissions $\mathrm{d}^{-1}$.

Long-term (multi-year) movements and reproduction were identified by visually resighting branded sea lions during annual dedicated surveys between November 2009 and July 2015. Most surveys were conducted by observing haulouts and rookeries from nearby skiffs, with land-based observation possible at some rookeries. Most observations were collected during dedicated brand-resight cruises visiting Southeast Alaska and Gulf of Alaska haulouts and rookeries in June and July each year. More intensive land-based surveys were conducted annually at the Lowrie Island rookery mid-May through mid-July. The summer breeding season observations were augmented by aerial surveys (primarily during spring at the seasonal Dry Bay/Alsek River haulout; Fig. 3) and both periodic (e.g. Benjamin Island, Gran Point; Fig. 3) and opportunistic (e.g. Inian Islands, South Marble Island; Figs. 2 \& 3) skiff-based visits during other months (Jemison et al. 2013). Survey effort was variable across the study area, with extra effort (repeat visits over 2-3 d) made at breeding rookeries and largersized haulouts. Individual marked sea lions were observed using binoculars, and all identities were confirmed by making digital photographs of brands for comparison to a photographic catalog of known branded sea lions. Pupping of females was determined by observing marked adult females and recording behaviors, using standardized behavior codes, suggesting presence of a dependent pup (i.e. nursing, nuzzling, following, and reuniting; Hastings \& Jemison 2016). Breeding of males was identified by observing territorial behavior (i.e. males appeared to defend space with females) on the rookeries and photo-confirming their identities.

\section{Telemetry data processing and analysis}

The SPLASH tags were programmed to provide Argos system location estimates at irregular time 


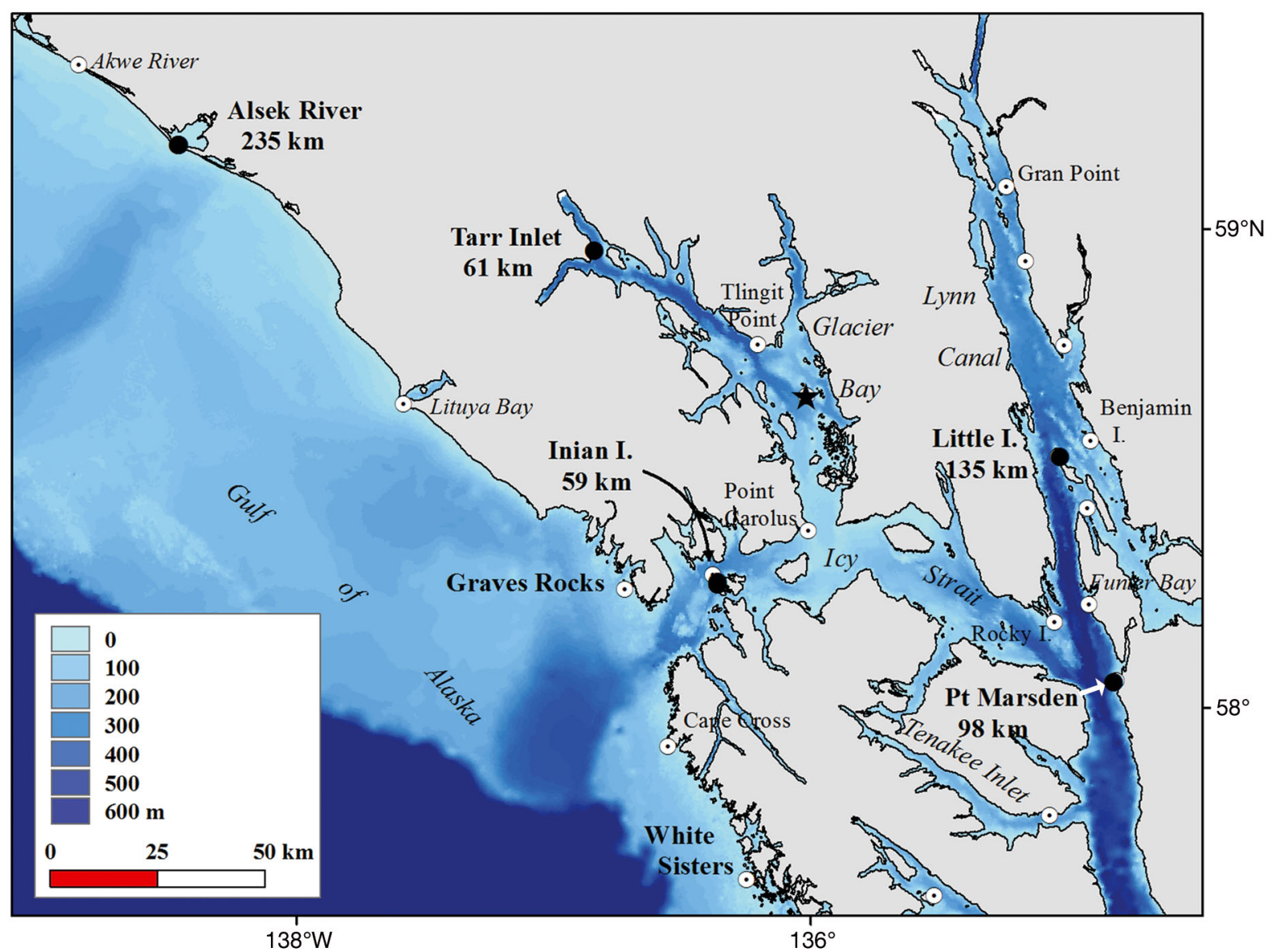

Fig. 3. Glacier Bay region, indicating range of 7 Steller sea lion juveniles captured at South Marble Island (indicated by dark star) and moving throughout northern Southeast Alaska during winter 2009 to 2010. Dark circles indicate haulouts occupied by juveniles; dotted circles indicate other haulouts available. Shortest path movement distances from the point of capture to each haulout used are indicated adjacent to haulout names. Seafloor depth is indicated by shading and provides context to Table 4 and text

intervals. Tags were also programmed to summarize dive depth (the count of dives within fourteen $50 \mathrm{~m}$ depth ranges during 4 daily $6 \mathrm{~h}$ periods) and the proportion of time at depth (the proportion of time spent in each of 14 depth ranges, including a surface category, during 4 daily $6 \mathrm{~h}$ periods) and to report the depth of the deepest dive per $24 \mathrm{~h}$ period (accurate to $2 \mathrm{~m}$ ). Tags also reported a continuous haulout timeline indicating whether each of seventy-two $20 \mathrm{~min}$ intervals $\mathrm{d}^{-1}$ were majority wet or majority dry and also provided a sporadic indicator of whether the tag was in wet or dry mode. Time-at-depth summaries were trimmed using the haulout timeline data such that only the time spent off the haulout was used for analysis. Location estimates and data provided via the Argos system were extracted using DAP 2.0 software (Wildlife Computers 2009) into a Microsoft Access database and queried for analysis.

A haulout residency calendar was constructed to identify when particular haulouts were used by indi- vidual sea lions. Argos locations coded wet or dry were plotted (ArcMap 10.2, ESRI) against a map of known haulout locations and manually reviewed in sequence to determine the start date and end date of each sea lion's residency at a particular haulout. From this information, inter-haulout movements were identified and minimum haulout-to-haulout movement distances measured.

For each central-place haulout used by each individual, we summarized characteristics of diving and swimming behavior relevant to potential prey as determined from previous studies (Abookire et al. 2002, Robards et al. 2003, Arimitsu et al. 2008, Womble et al. 2014). Maximum dive depths made by individual sea lions while resident at the haulout were summarized (mean $\pm \mathrm{SD}$ ) for each $6 \mathrm{~h}$ dive period. Maximum dive depths for each $6 \mathrm{~h}$ dive period were also linked to the Argos location estimate(s) which occurred during the same period. We compared these depth-linked locations to an under- 
lying model of seafloor depth (Rehberg \& Gelatt 2003) to determine the proximity of an individual Steller sea lion's diving to the seafloor, an indicator of mid-water vs. benthic diving. To determine the relative focus on diving during daylight vs. darkness, an indicator of foraging effort on vertically migrating prey vs. light-insensitive prey, we calculated a ratio of the proportion of time spent submerged during daylight vs. the proportion of time spent submerged during darkness. Time submerged was calculated as the fraction of time spent deeper than the surface category within the trimmed time-at-depth summaries. Daylight hours were bounded by civil twilight as calculated by the US Naval Observatory sunrise/sunset calculator for Gustavus, Alaska (http://aa.usno.navy. mil/data/docs/RS_OneYear.php, accessed on 29 October 2010). Values $>0$ indicated that a greater proportion of daylight hours were spent diving, values $<0$ indicated a greater proportion of night hours were spent diving, and values centered about 0 indicated no difference. The single maximum depth readings recorded each day (accurate to $2 \mathrm{~m}$ ) were presented in descriptive form because sample sizes were too small to allow inferences of population effects after accounting for age class and location (Rehberg et al. 2009).

Mass of captured sea lions was compared among 3 areas (Glacier Bay [present study], elsewhere within Southeast Alaska, and Prince William Sound [Rea et al. 2016]; Fig. 1), age class (5 mo old pup and 17 mo old juvenile), and sex using an ANOVA (R Core Team 2014), and post hoc comparisons were performed using the Tukey's HSD test. Fitted values were plotted against residuals and quantile-quantile plots made to assess whether model assumptions were met.

\section{RESULTS}

We captured twenty-four 5 mo old Steller sea lion pups (16 female, 8 male) and seven 17 mo old juveniles (2 female, 5 male; Table 1 ) at the South Marble Island haulout in central Glacier Bay, Alaska (Fig. 2). A subset of 5 pups (3 female, 2 male) and all 7 juveniles were instrumented with SPLASH tags (Table 2). Pups were tracked for $77 \mathrm{~d}$ (median; range 44-139) and juveniles for $75 \mathrm{~d}$ (median; range 36-79), far short of the intended tag endurance (240 d), with 6 of the 8 head-mounted SPLASH tags failing prematurely within $7 \mathrm{~d}$ of each other. Subsequent observation of 4 head-mounted tags revealed their antennae had been sheared off at the base.

\section{Winter movement, diving, and foraging behavior}

All but 3 pups (1 female and 2 males, all nontagged) were visually observed alive after the end of their first winter at Glacier Bay. The 5 pups tracked by satellite from November through January remained within Glacier Bay for the duration of tag deployments (Fig. 2). Two pups (female $=740$, male =745) moved $61 \mathrm{~km}$ northward from South Marble Island to Tarr Inlet in the upper West Arm of Glacier Bay on 23 December 2009, whereas the remaining 3 pups used the South Marble Island haulout for the duration of their tag deployments. Pups at South Marble Island dove to maximum daily depths of $82 \pm$ $24 \mathrm{~m}$ (mean $\pm \mathrm{SD}, \mathrm{n}=3$ ), whereas pups at Tarr Inlet increased their diving depths to $158 \pm 34 \mathrm{~m}(\mathrm{n}=2)$. Pups at South Marble Island were tracked diving in waters $96 \pm 56 \mathrm{~m}$ deep (maximum depth $383 \mathrm{~m}$; Fig. 2). The maximum dive depths made by pups in this area reached $70 \pm 6 \%$ (mean $\pm \mathrm{SD}$ ) of the water depth available to them. Two pups at Tarr Inlet swam in deeper waters, $204 \pm 101 \mathrm{~m}$ (maximum depth 412 m, Fig. 2), but their diving used a shallower fraction of the water column available to them, coming within $60 \pm 5 \%$ of water depth. Pups in all regions of Glacier Bay favored daytime diving, with a day:night proportion of time diving ratio of $0.20 \pm 0.06$ (mean \pm $\mathrm{SD}, \mathrm{n}=5$ pups)

All juveniles except 1 male were visually observed alive by late March, the end of the 2009-2010 winter.

Table 2. SPLASH tags deployed on 5 pup (5 mo old) and 7 juvenile (17 mo old) Steller sea lions at South Marble Island, Glacier Bay. Tracking duration and geographic range of movement from the initial capture site are indicated. Except for $=740$, all tags suffered premature failure; despite greater longevity of tracking, behavior of this sea lion was unremarkable and retained within summaries. F: female; M: male

\begin{tabular}{|lccccc|}
\hline $\begin{array}{l}\text { Animal } \\
\text { identifier }\end{array}$ & Sex & $\begin{array}{c}\text { Capture } \\
\text { date }\end{array}$ & $\begin{array}{c}\text { Age } \\
\text { (mo) }\end{array}$ & $\begin{array}{c}\text { Deployment } \\
\text { duration (d) }\end{array}$ & Range \\
\hline$=740$ & F & 13 Nov 09 & 5 & 139 & Glacier Bay \\
$=741$ & F & 13 Nov 09 & 5 & 62 & Glacier Bay \\
$=743$ & F & 13 Nov 09 & 5 & 93 & Glacier Bay \\
$=744$ & M & 13 Nov 09 & 5 & 44 & Glacier Bay \\
$=745$ & M & 13 Nov 09 & 5 & 36 & Glacier Bay \\
$=7521$ & F & 7 Nov 09 & 17 & 74 & Glacier Bay \\
$=727$ & F & 8 Nov 09 & 17 & 78 & Outer coast \\
$=719$ & M & 6 Nov 09 & 17 & 75 & Icy Strait \\
$=720$ & M & 6 Nov 09 & 17 & 79 & Outer coast \\
$=722$ & M & 7 Nov 09 & 17 & 73 & Icy Strait \\
$=4=$ & M & 7 Nov 09 & 17 & 77 & Glacier Bay \\
$=742$ & M & 13 Nov 09 & 17 & 44 & Lynn Canal \\
\hline
\end{tabular}


Juveniles were satellite tracked from November through January, with both females and 1 male remaining within Glacier Bay throughout the period (Fig. 2). Juvenile Steller sea lions in Glacier Bay alternated time foraging in areas between South Marble Island and fjords within Glacier Bay (Fig. 2), diving to maximum daily depths of $152 \pm 84 \mathrm{~m}(\mathrm{n}=7)$ and reaching $75 \pm 4 \%$ of the seafloor depths available to them (see Table 4). By December, 2 juvenile males moved out of Glacier Bay to the Inian Islands $(59 \mathrm{~km}$ southward; Fig. 3) in Cross Sound, making dives 198 $\pm 49 \mathrm{~m}$ deep and reaching $57 \pm 9 \%$ of seafloor depth. One male travelled west through Icy Strait and Cross Sound and eventually northward $235 \mathrm{~km}$ to the outer coast near the Yakutat Forelands on 7 December and remained in the vicinity of the Alsek River and the Fairweather Grounds through 24 January, making dives of $88 \pm 47 \mathrm{~m}$ and using $91 \%$ of water depth available. One male travelled eastward $145 \mathrm{~km}$ to Point Marsden in Chatham Strait and to Little Island, an ephemeral haulout site, in Lynn Canal, making dives of $316 \pm 32 \mathrm{~m}$ within average water depths of $406 \mathrm{~m}$ and using $73 \%$ of seafloor depth.

Unlike pups, juveniles exhibited variability in diving behavior across individuals and regions. Juveniles resident at South Marble Island spent similar time diving in both daylight and darkness, with a day:night ratio of $0.03 \pm 0.07$ (resident for 255 animal-days; Fig. 4). Two juveniles travelling just outside Glacier Bay to the Inian Islands shared a remarkably similar preference for daylight diving (ratio of $0.28 \pm 0.0007$, resident for 80 animal-days; Fig. 4). Daylight preference was similarly observed for single individuals on the outer coast and at Tarr Inlet, and 2 juveniles showed a darkness preference at Hugh Miller Inlet in the West Arm of Glacier Bay and Little Island (Fig. 4), but these residencies were shorter than others.

\section{Body condition}

Male pups captured at South Marble Island in Glacier Bay were heavier than females $(77.4 \pm 6.5$ vs. $64.7 \pm$ $7.5 \mathrm{~kg}$ ), and male juveniles were heavier than females $(135.0 \pm 30.0 \mathrm{vs}$. $114.0 \pm 2.8 \mathrm{~kg})$. The mass of pups cap- tured at South Marble Island was not significantly different from same-age mass of pups of the wDPS in Prince William Sound $\left(F_{1,2}=14.2, \mathrm{p}=0.67\right)$, but Glacier Bay pups were significantly heavier than sameage pups from elsewhere in Southeast Alaska (males $14.2 \mathrm{~kg}$ heavier, females $9.1 \mathrm{~kg}$ heavier; Table 3). In contrast, the juvenile male sea lions had no significant overall geographic difference in mass $\left(F_{1,2}=\right.$ $10.8, \mathrm{p}=0.69$ ), but female juveniles from Glacier Bay were significantly heavier than those from elsewhere in Southeast Alaska (females $13.1 \mathrm{~kg}$ heavier; Table 3).

\section{Demographic origins}

Of 24 pups and 7 juveniles captured in Glacier Bay, genetic analysis was successful for 20 and 5, respectively (Table 1); 6 individuals were not assigned to a DPS due to missing samples or low statistical power. This revealed that $60 \%$ of the pups were assigned to the wDPS and $40 \%$ to the eDPS based on mtDNA frequencies. By contrast, most juveniles (4 of the 5

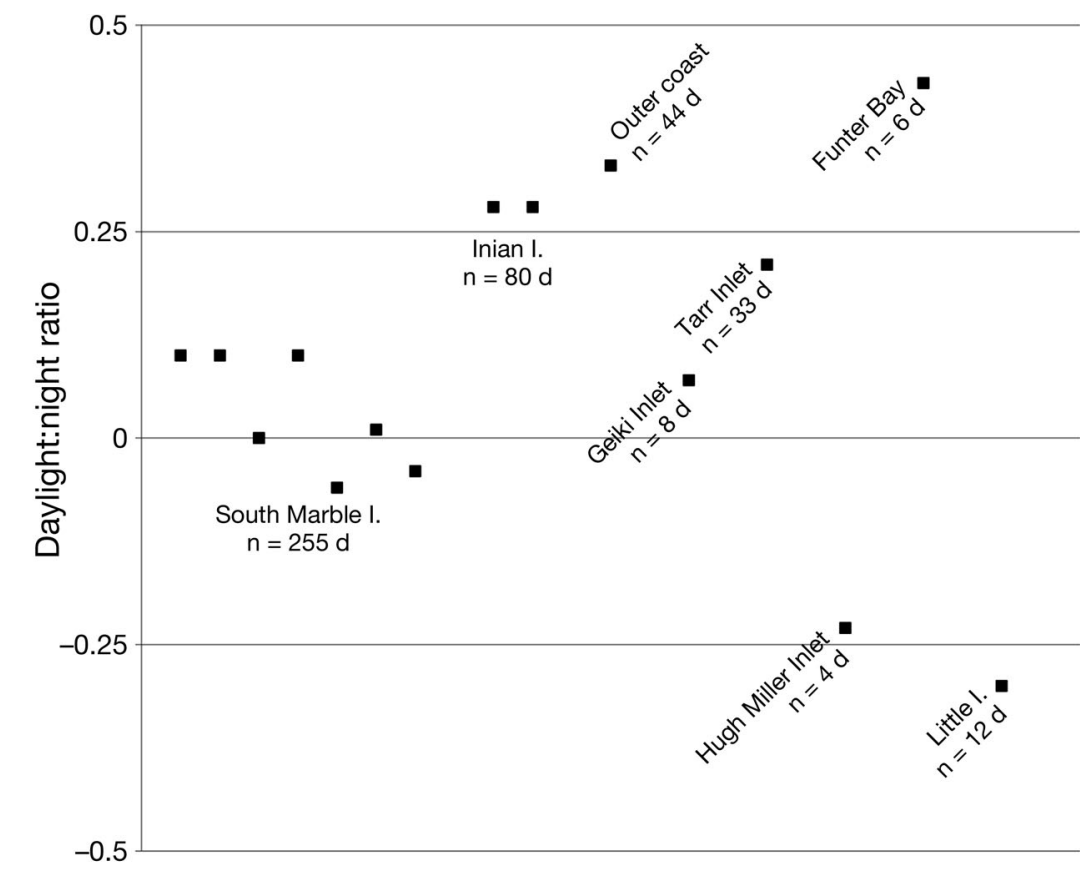

Fig. 4. Relative diurnal focus of diving behavior at the 8 central-place haulouts utilized by 7 Steller sea lion juveniles during November 2009 to January 2010. Day:night ratio values $>1$ indicate greater proportion of daylight hours were spent diving than the proportion of darkness hours spent diving, values $<1$ indicate the opposite, and values near zero indicate similar diving focus during daylight and darkness. Points represent the ratio for 1 individual during its residency at a central-place haulout indicated by name. South Marble Island was visited by 7 sea lions, Inian Islands were visited by 2 sea lions, and the remaining haulouts were used by 1 individual only. The number of days sea lions were resident at each location is indicated 
Table 3. Mass of 17 pup (5 mo) and 7 juvenile (17 mo) Steller sea lions captured during this study in Glacier Bay (South Marble Island, 2009), contrasted with sea lions previously captured elsewhere in Southeast Alaska (Benjamin, Hazy, and Brothers islands, 1998-2002) and sea lions captured in Prince William Sound (Perry and Glacier islands, 2001-2007). Numbers in parentheses indicate number of individuals. Similar superscripts indicate no significant difference. F: female; M: male

\begin{tabular}{|c|c|c|c|c|}
\hline \multirow{2}{*}{$\begin{array}{l}\text { Age } \\
\text { (mo) }\end{array}$} & \multirow[t]{2}{*}{ Sex } & \multicolumn{3}{|c|}{ - Mass (mean $\pm \mathrm{SD}$ ) } \\
\hline & & Glacier Bay & Southeast Alaska & Prince William Sound \\
\hline 5 & $\mathrm{~F}$ & $64.7 \pm 7.5(13)^{\mathrm{a}}$ & $55.6 \pm 9.7(13)$ & $64.2 \pm 7.6(44)^{\mathrm{a}}$ \\
\hline 5 & M & $77.4 \pm 6.5(4)^{\mathrm{b}, \mathrm{c}}$ & $63.2 \pm 10.0(1) 1^{\mathrm{b}}$ & $76.2 \pm 10.0(37)^{\mathrm{c}}$ \\
\hline 17 & $\mathrm{~F}$ & $114.0 \pm 2.8(2)$ & $100.9 \pm 6.2(4)$ & $124.7 \pm 11.2(12)$ \\
\hline 17 & $\mathrm{M}$ & $135.0 \pm 30.3$ & $123.0 \pm 17.6(9)$ & $141.2 \pm 19.5(9)$ \\
\hline
\end{tabular}

having stock assignments available) were assigned to the eDPS. Long-term brand-resight observations through summer 2015 indicated that most Steller sea lions in this study remained within the same area they occupied during the brief 3 mo period they were tracked with the SPLASH tags immediately after capture, with a few seasonal and individual exceptions. Of 13 sea lions (10 female, 3 male) observed through 2015, 8 were observed at the seasonal ephemeral haulout at the Alsek River (235 km swimming distance; Fig. 3). Only 2 male sea lions travelled away from northern Southeast Alaska into Prince William Sound between 2009 and 2015 (Fig. 1).

By the summer 2015 breeding season, 14 of the 18 surviving female pups and juveniles (now at age 6-7 yr) were observed during brand-resight work at either Graves Rocks $(\mathrm{n}=8)$ or White Sisters $(\mathrm{n}=6)$, the nearest breeding rookeries to Glacier Bay $(84 \mathrm{~km}$ and $142 \mathrm{~km}$ swimming distance, respectively; Fig. 3). Strong evidence indicated 11 of these females produced pups: 8 females were observed nursing and 3 were interacting extensively with adjacent pups (mutual nuzzling, pups following females, and pups reuniting with females). No sea lions captured in Glacier Bay were observed at other rookeries besides Graves Rocks or White Sisters prior to breeding. Over a similar timespan, no males were observed holding territories on the breeding rookeries, as the oldest males were $7 \mathrm{yr}$ of age, too young to defend and maintain a breeding territory. Five of these males were observed at the Graves Rocks and White Sisters rookeries through 2015, and 1 travelled to the wDPS rookery at Seal Rocks (717 km distant) near Prince William Sound in the central Gulf of Alaska (Fig. 1). One male was observed with a fishing lure at the edge of its mouth in October 2014 at Port Frederick, 75 km southeast of South Marble Island, and harvested at that site the same day by a subsistence hunter.

\section{DISCUSSION}

The $16.6 \%$ annual growth in abundance of Steller sea lions at South Marble Island over the 18 yr (19912009) prior to this study (Mathews et al. 2011), the 0.569 survival rate of females born at nearby Graves Rocks to maturity (Hastings et al. 2011), and documentation of wDPS females permanently emigrating to and breeding at Graves Rocks (Jemison et al. 2013, O'Corry-Crowe et al. 2014) suggest that favorable conditions occur in the Glacier Bay region for Steller sea lions. There are several factors that may make the Glacier Bay region favorable for Steller sea lions and may contribute to increased survival, decreased mortality, and/or increases in immigration rates of sea lions from other areas. Glacier Bay is a recently deglaciated fjord that has undergone rapid advances and retreats of tidewater glaciers over the last $225 \mathrm{yr}$ and is a highly dynamic and productive marine environment. Previous studies have documented high levels of primary productivity, sustained levels of mixing (Etherington et al. 2007), high concentrations of zooplankton and forage fish (Robards et al. 2003, Arimitsu et al. 2008), and the relatively recent colonization of Glacier Bay by Pacific salmon Oncorhynchus sp. (Milner \& Bailey 1989), an important seasonal prey resource for Steller sea lions (Sigler et al. 2009). Large aggregations of marine mammals including humpback whales Megaptera novaeangliae, harbor seals, sea otters Enhydra lutris, and sea lions (Mathews \& Pendleton 2006, Womble et al. 2010, Mathews et al. 2011, Saracco et al. 2013, Williams et al. 2017) occur in Glacier Bay, and collectively these studies suggest that the Glacier Bay region provides productive foraging areas and a rich prey environment for top predators in the nearshore marine environment. Glacier Bay proper and adjacent coastal waters within Glacier Bay National Park also comprise a marine protected area (MPA) with regulations to minimize threats to Steller sea lions and other marine mammals via approach regulations and closures (Womble \& Gende 2013). Subsistence hunting of sea lions is prohibited in Glacier Bay, and commercial fishing within the MPA boundary is currently being phased out (Mackovjack 2010); these protections could result in decreased sea lion harassment and/or mortality (Mathews et al. 2011). Herein we discuss the results from this study focused on sea lion diving behavior and movement in the context of prey avail- 
ability in the region, which has been quantified from previous studies.

Sea lions tracked in this study remained in the Glacier Bay region during winter (November-March), a time that demands the highest predicted daily food requirements for sea lions (Winship et al. 2002), providing support for the premise of a rich prey environment. Similarly, the choice of females to remain in the Glacier Bay region, or at the nearest rookery (White Sisters) to breed, indicates they find prey resources locally for reproduction. Finally, sea lions moved to locations having known prey abundance in the region (Robards et al. 2003, Womble et al. 2005, 2009, Womble \& Sigler 2006, Sigler \& Csepp 2007). Collectively, these findings suggest that adequate prey resources are available to support sea lions in this region and thus reduce the need for them to emigrate elsewhere.

Haulout selection is important to this generalist, opportunistic predator (Trites et al. 2007), which periodically moves to different locations within its range to exploit seasonally abundant and accessible prey (Womble \& Sigler 2006, Sigler et al. 2009). Income breeders (Boyd 1998) such as Steller sea lion females, rely on foraging throughout a prolonged lactation period to provision their young and, thus, depend on prey near the haulouts where their dependent pups are waiting. This foraging strategy is readily observed visually and by remote satellite tracking, because Steller sea lions reside at central-place haulouts adjacent to seasonal prey hot spots for weeks to months (observed in Southeast Alaska by Gende \& Sigler 2006). This strategy reduces predation risk and energy expenditure by allowing short-distance and -duration foraging trips (Raum-Suryan et al. 2004, Fadely et al. 2005, Rehberg et al. 2009) interspersed with terrestrial rest and suckling bouts (McLaughlin \& Montgomerie 1989). The Steller sea lions captured in Glacier Bay remained within the Glacier Bay region throughout the winter (Fig. 3), sharing common usage of the White Sisters and Graves Rocks rookeries and Inian Islands haulout (Fig. 3). This is similar to observations in previous work by Raum-Suryan et al. (2004, their Fig. 11, the northern outer coast cluster), which demonstrated that sea lions tracked in this region formed a smaller, isolated grouping of sea lions, centered among Glacier Bay, Graves Rocks, and White Sisters, relative to the wider-ranging groupings of sea lions tracked elsewhere in Southeast Alaska.

Examination of the known aggregations of prey available may, in part, explain why sea lions exhibit high fidelity to the Glacier Bay region during winter.
Generally throughout Southeast Alaska, winter sea lion diet consists mainly of gadids $(50 \%)$, forage fish $(14 \%)$, cephalopods $(8 \%)$, flatfish $(8 \%)$, and some Pacific salmon (1\%; Winship \& Trites 2003). However, focal studies of sea lion diet in Lynn Canal and Frederick Sound (regions east and south of the present study) suggest there is regional and seasonal variation in the prey species consumed by sea lions. In both regions, seasonally available prey species such as eulachon, capelin Mallotus villosus, and northern lampfish Stenobrachius leucopsarus were important during spring (Womble \& Sigler 2006, Sigler et al. 2009).

Specific to the Glacier Bay region, the prey assemblage includes dense forage fish schools including Pacific herring Clupea pallasii, capelin, and northern lampfish (Arimitsu et al. 2007, 2008), which are rich in lipid content (Van Pelt et al. 1997) and in some regions occur in shallower waters during daylight than other forage fish consumed by Steller sea lions (Abookire et al. 2002). Likewise, sea lions in this area showed a daylight preference in foraging behavior (Fig. 4) and foraged at shallower depths relative to other locations (Fig. 3). Although food habits have not been examined for sea lions in this area, capelin have been documented in Steller sea lion scats during autumn, winter, and spring in other regions of Southeast Alaska. Previous studies have shown that capelin are abundant in Glacier Bay and likely serve as an important prey resource for sea lions and other marine predators. In addition, during summer months, prey were found higher in density and shallower in the water column (<100 $\mathrm{m}$ depth) in the Beardslee Entrance (near South Marble Island haulout) compared to Johns Hopkins Inlet (near Tarr Inlet haulout; our Fig. 2; Womble et al. 2014). Similarly, sea lions in this study dove deeper near Tarr Inlet, a deeper habitat, than at South Marble Island, a shallower habitat. Shallower prey depths in lower Glacier Bay likely provide opportunities for more efficient foraging by Steller sea lions given other marine predators including harbor seals, sea lions, and humpback whales have been observed foraging in this region regularly (Womble et al. 2014). Dense aggregations of walleye pollock, sand lance, salmon, and capelin have also been documented in the lower bay (Robards et al. 2003, Arimitsu et al. 2008).

Steller sea lions occupy an ephemeral spring haulout at Tarr Inlet in upper Glacier Bay, and sea lions have been observed actively foraging in the upper reaches of Tarr Inlet (Fig. 2; Womble et al. 2005, 2009, J. N. Womble pers. obs.), likely taking advantage of seasonally available prey. Pacific sand lance 
Ammodytes hexapterus, and herring are present in the warmer mid-bay waters near South Marble Island haulout, whereas walleye pollock and capelin are found in the cooler waters to the north at Tarr Inlet (Arimitsu et al. 2007). Any benefit gained by the longer-distance movements juveniles are making to distant foraging areas outside Glacier Bay (Fig. 3) does not appear to be required by adult females tending the pups tracked in this study (Fig. 2), who apparently find sufficient quantities of local prey despite the additional demands of nursing their pups. Remaining in Glacier Bay may also reduce predator exposure for the younger pups, a less important consideration for the older, longer-ranging juveniles.

In Cross Sound, west of Glacier Bay, several juveniles spent time foraging in the tide rips adjacent to the Inian Islands (Fig. 3), behavior also observed during monthly aerial surveys of Steller sea lions (Womble et al. 2009) and skiff-based surveys during summer (Alaska Department of Fish and Game [ADF\&G] unpubl. data). North Inian Pass is a dynamic area comprised of a narrow channel with strong tidal currents that links the inside waters of Icy Strait with the Gulf of Alaska. It is also a primary migratory corridor for Pacific salmon, a seasonally important prey species for sea lions, entering inside waters from spring through autumn. These tide rips also aggregate other important prey, as Steller sea lions have been photo-documented feeding on rockfish, flatfish, and gadids here (ADF\&G unpubl. data, J. N. Womble pers. obs.)

Farther afield, during December, 1 juvenile made a long-distance move north along the outer coast to reside at the mouth of the Alsek River $(235 \mathrm{~km}$; Fig. 3). Large numbers of sea lions gather here during late winter and spring (February-May) to feed on pre-spawn and spawning eulachon Thaleichthys pacificus (Womble et al. 2005). The Alsek and nearby Akwe rivers support the largest known seasonal aggregation of Steller sea lions in Alaska outside the breeding season (ADF\&G and US Forest Service unpubl. data). Between 2012 and 2015, 8 sea lions branded in this study were also photo-documented at this location at least once during the spring eulachon run (ADF\&G unpubl. data). Eulachon are one of the most energy-rich prey species consumed by sea lions and likely important for sea lions prior to the energetically demanding reproductive season (Womble et al. 2005). The earlier arrival of this individual at the Alsek River possibly indicates the sea lion was targeting additional prey species. The Alsek River is at the head of a submarine canyon leading inward from deeper waters, and, unlike other locations used by juvenile sea lions from Glacier Bay, the shelf break is accessible from this location (Fig. 3). Piatt et al. (2006) suggested these northern Gulf of Alaska canyons induce upwelling and enhance vertical mixing over the shallow waters of the continental shelf, concentrating short-tailed albatross Phoebastria albatrus feeding behavior over localized, predictable hot spots of prey in similar fashion suggested for Steller sea lions by Sigler et al. (2009). Indeed, the sea lion tracked over winter here performed the shortest trips and shallowest diving observed in this study (Figs. 3 $\& 4$ ), relative to sea lions foraging at more inland locations. Individual female harbor seals captured in Glacier Bay also use this region of the Gulf of Alaska extensively, during autumn, winter, and spring, suggesting this area may be an important foraging region for pinnipeds in general (Womble \& Gende 2013).

One male juvenile $(=724)$ appeared to use a predictable, dense food supply by moving $135 \mathrm{~km}$ eastward to Little Island haulout in Lynn Canal, which is typically occupied late summer through early autumn (Fig. 3; Womble et al. 2009). At nearby Benjamin Island, Pacific herring was the most common species found in sea lion diets and comprised $>80 \%$ of pelagic prey biomass available to them (Womble \& Sigler 2006). Peak seasonal herring biomass coincided with this male's visit (Sigler \& Csepp 2007), during the winter season when herring energy content is highest (Vollenweider et al. 2011). Womble et al. (2009) identified overwintering herring aggregations such as this as primary hot spots correlated with large numbers of nearby hauled-out sea lions. Walleye pollock (a gadid, Gadus chalcogrammus) was also important throughout the year for sea lions but was much lower in available biomass (Womble \& Sigler 2006). While this sea lion's movement and diving reflect a response to this prey hot spot, more dispersed and less energy-dense prey were also available throughout Southeast Alaska. Walleye pollock was the most abundant and widely distributed forage species during summer, found in 2 locations occupied by juvenile Steller sea lions in this study (Fig. 3): Glacier Bay and the Inian Islands (Arimitsu et al. 2007, McGowan et al. 2016). Both walleye pollock and North Pacific hake Merluccius productus were available year round and consumed throughout Southeast Alaska (Womble \& Sigler 2006, Womble et al. 2009), with hake occurring at deeper depths than pollock (Csepp et al. 2011). These 3 mesopelagic fish taxa were not found at the seafloor, with peak energy density of both pollock and herring found shallower than 150 m during December (Sigler et al. 2009), a 
good match to the less-than-benthic diving performed by juveniles in this study in all locations (Table 4).

Foraging Steller sea lions share this region of Southeast Alaska with other piscivores during winter. Harbor seals, bald eagles Haliaeetus leucocephalus, and humpback whales are observed in high prey density locations along with Steller sea lions in Lynn Canal (Fig. 3; Martson et al. 2002, Sigler \& Csepp 2007). Harbor seals consume similar prey to sea lions in Glacier Bay (Herreman et al. 2009, Blundell et al. 2011), including capelin, herring, and pollock, but the seal population has undergone a precipitous decline (Mathews \& Pendleton 2006, Womble et al. 2010), in contrast to the rapidly increasing sea lion numbers (Mathews et al. 2011). Like sea lions, harbor seals in areas associated with floating glacial ice habitat in Glacier Bay have available to them great depths (Johns Hopkins Inlet, approximately $370 \mathrm{~m}$ ), but $95 \%$ of seal dives are made to $<100 \mathrm{~m}$ (Womble et al. 2014) as they pursue epipelagic prey. In contrast, the Steller sea lions occupying similar deep glacial habitat in this study (Tarr Inlet, Geike Inlet; Table 4) are reaching 83 to $90 \%$ of the available bottom depth. While this difference might allow sea lions to acquire more abundant prey at depth, the difference in diving may not indicate competitive exclusion of harbor seals by sea lions. Instead, Womble et al. (2014) suggest that harbor seals are using these deeper sites, with their less abundant prey, because the floating ice provides stable resting platforms and refuge from predation.

Foraging behavior, or lack thereof, of pups spending the winter in Glacier Bay met our expectations from previous studies: pup diving was shallower, less frequent, and did not show a nighttime focus or seasonal response in the same way as older juvenile behavior, which seems to more closely respond to prey habits (Raum-Suryan et al. 2004, Pitcher et al. 2005, Rehberg \& Burns 2008). Pups in this study remained in Glacier Bay (Fig. 2), were observed suckling, and were likely dependent on adult females for nutrition. This area likely protected pups from winter storms relative to the more exposed habitat used by juveniles (Fig. 3). Because the unweaned pups were able to remain at the South Marble Island and Tarr Inlet haulouts through the winter, and the typical attendance cycle of dams and their dependent pups during winter in Southeast Alaska is $2 \mathrm{~d}$ (Trites \& Porter 2002), adult female sea lions clearly had sufficient access to prey resources in or near Glacier Bay to support their pups through the winter months. Furthermore, 5 of the 7 juveniles were observed still suckling after the tracking portion of this study concluded, at 17 mo of age and older. Stable isotope

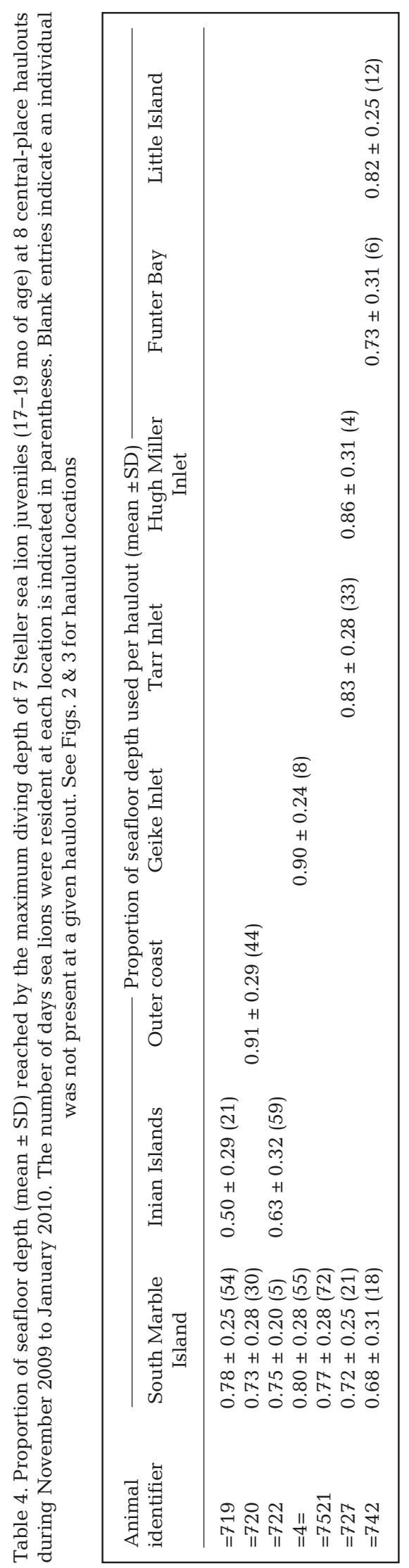


trends along the vibrissae of sea lions captured in this study (ADF\&G unpubl. data, L. Rea pers. comm.) provided another indication of whether or not individuals were weaned by demonstrating whether the trophic level of their diet had changed at time of capture (i.e. from higher level based on milk to lower level based on direct fish consumption). These stable isotope results corroborated the suckling observations well: except for 1 juvenile with a weak weaning signal (=742, also never observed suckling; L. Rea pers. comm.), juveniles and pups in this study were still nutritionally dependent on their dams.

As in previous tracking studies (Raum-Suryan et al. 2004) and brand-resight movement studies (RaumSuryan et al. 2002, Jemison et al. 2013), the longestrange movements tracked by satellite telemetry (in the short term) and brand-resight observations (over the long term) were accomplished by males. During this study (2009-2015), these males had not yet reached maturity (9-13 $\mathrm{yr}_{\text {; }}$ Pitcher et al. 2001) and had not been observed holding territories on breeding rookeries (Table 1). The longest movements documented during this study were based on brandresight data collected through 2015: 2 males moved westward into the wDPS. One male (=744) moved between Prince William Sound (Fig. 1) in July 2012, 2013, and 2014 and the Alsek River in spring 2013 and 2014. A second male $(=720)$ was observed at Glacier Island in Prince William Sound (Fig. 1) at age 4 and thereafter observed at Graves Rocks, Inian Islands (specifically, Northwest Inian Island and Middle Pass Rock), South Marble Island, and the Alsek River. Given that males have been documented moving $>3500 \mathrm{~km}$ from natal rookeries in summer to remote haulouts in winter (Jemison et al. 2013), the longest movements in this study were small by comparison, supporting the idea that adequate prey resources are available in the Glacier Bay region. A study examining sex- and rookery-specific patterns of movement indicated that sea lions born in the Glacier Bay region were less likely to travel west into the wDPS than animals born in Prince William Sound to move east into the eDPS (Jemison et al. 2013). Because there is strong genetic division between the eDPS and the wDPS (O'Corry-Crowe et al. 2014) and microsatellite analysis demonstrates little malemediated gene flow between the populations (Hoffman et al. 2006), males captured in Glacier Bay are unlikely to move away from the Glacier Bay region and westward into the wDPS at maturity. Indeed, Hastings et al. (2011) found males born in this area that did disperse west into the wDPS had lower survival to age 7 than males who remained in this area.
The sea lions captured in Glacier Bay during winter have a similar blend of mtDNA-derived (maternal) genetic stock origins (Table 1) to those observed at the nearby newly colonized Graves Rocks rookery (Gelatt et al. 2007, O'Corry-Crowe et al. 2014), where the newborn cohorts consist of roughly half eDPSand half wDPS-origin individuals. Because this area is situated on the interface of genetically and demographically distinct population segments, the growth in sea lion numbers here (Mathews et al. 2011) would seem most naturally to be an expansion of the thriving eastern population on its northern fringe. Hoffman et al. (2006) speculated as much, indicating that the declining wDPS was not being replenished by the expanding eDPS despite their close demographic proximity. Instead, growth in this area is more likely related to colonization of the growing eDPS by individuals emigrating from the wDPS (O'Corry-Crowe et al. 2014). This study corroborates these observations by demonstrating the short-term tendency of sea lions captured at South Marble Island to remain within a limited foraging radius (Figs. 1 \& 2). In the longer term, young females captured here remained in this area to breed, years later (Table 1), at the Graves Rocks rookery. Regardless of whether these females are eDPS or wDPS in genetic origin, if current survival trends continue, their offspring will be twice as likely to survive through age 7 than pups born at other Southeast Alaska rookeries (Hastings et al. 2011). Survival trends imply that this area provides sufficient resources to support Steller sea lions, in robust condition, throughout their life cycle. Several lines of evidence from our study and others suggested that the Glacier Bay region, a site of rapid population growth and colonization (Mathews et al. 2011), appears to provide the resources and conditions for sea lions captured here to remain here into their reproductive years and continue the growth of this genetically mixed population on the interface of the eDPS and wDPS.

The Glacier Bay region is dynamic in terms of productivity, prey availability, and the concentrations of upper trophic level marine predators that occur here (harbor seals, Steller sea lions, humpback whales; Womble et al. 2010, Mathews et al. 2011, Saracco et al. 2013, Williams et al. 2017); thus, future interdisciplinary studies aimed at elucidating the linkages between primary productivity, prey availability, and the diving and foraging behavior of sea lions and other species will be important. A follow-up study, to mark a new cohort of pups born at rookeries adjacent to Glacier Bay and update our understanding of the genetic composition of Steller sea lions in this area, is in progress. 
Acknowledgements. This study was supported by NOAA grants NA08NMF4390544 and NA114390200 to ADF\&G. Field research and sample handling were authorized by NOAA Fisheries Permit 14325 (and earlier) issued to ADF\&G, US National Park Service Permit No. GLBA-2005SCI-0007, and ADF\&G Institutional Animal Care and Use Committee Assurance No. 09-28. Steller sea lion live capture was accomplished by K. Beckmen, A. Bryan, T. Gage, J. King, D. McAllister, L. Rea, P. Rivera, G. Snedgen, E. Van Burgh, and the authors onboard the ADF\&G R/V 'Medeia' operated by Capt. R. Sandstrom and crew. K. Hastings played a critical role managing the brand-resight database, which provided long-term movement, breeding, and weaning status. L. Rea provided access to and interpretation of unpublished stable isotope results inferring weaning status.

\section{LITERATURE CITED}

Abookire AA, Piatt JF, Speckman SG (2002) A nearsurface, daytime occurrence of two mesopelagic fish species (Stenobrachius leucopsarus and Leuroglossus schmidti) in a glacial fjord. Fish Bull 100:376-381

Allen BM, Angliss RP (2015) Alaska marine mammal stock assessments, 2014. US Department of Commerce, NOAA Tech Memo NMFS-AFSC-301

Arimitsu ML, Piatt JF, Romano MD, Douglas DC (2007) Distribution of forage fishes in relation to the oceanography of Glacier Bay National Park. In: Piatt JF, Gende SM (eds) Proc 4th Glacier Bay Sci Symp, October 26-28, 2004. US Geol Surv Sci Invest Rep 2007-5047, p 102-106

Arimitsu ML, Piatt JF, Litzow MA, Abookire AA, Romano MD, Robards MD (2008) Distribution and spawning dynamics of capelin (Mallotus villosus) in Glacier Bay, Alaska: a cold water refugium. Fish Oceanogr 17:137-146

Blundell GM, Womble JN, Pendleton GW, Karpovich SA, Gende SM, Herreman JK (2011) Use of glacial and terrestrial habitats by harbor seals in Glacier Bay, Alaska: costs and benefits. Mar Ecol Prog Ser 429:277-290

Boyd IL (1998) Time and energy constraints in pinniped lactation. Am Nat 152:717-728

Burkanov VN, Loughlin TR (2005) Distribution and abundance of Steller sea lions, Eumetopias jubatus, on the Asian coast, 1720's-2005. Mar Fish Rev 67:1-62

Csepp DJ, Sigler MF, Vollenweider JJ (2011) Seasonal abundance and distribution of pelagic and demersal fishes in southeastern Alaska. Fish Res 108:307-320

Etherington LL, Hooge PN, Hooge ER, Hill DF (2007) Oceanography of Glacier Bay, Alaska: implications for biological patterns in a glacial fjord estuary. Estuar Coasts 30:927-944

Fadely BS, Robson BW, Sterling JT, Greig A, Call KA (2005) Immature Steller sea lion (Eumetopias jubatus) dive activity in relation to habitat features of the eastern Aleutian Islands. Fish Oceanogr 14:243-258

Field WO (1947) Glacier recession in Muir Inlet, Glacier Bay, Alaska. Geogr Rev 37:369-399

Fritz LW, Towell R, Gelatt TS, Johnson DS, Loughlin TR (2014) Recent increases in survival of western Steller sea lions in Alaska and implications for recovery. Endang Species Res 26:13-24

Fritz LW, Sweeney KM, Towell RG, Gelatt TS (2016) Aerial and ship-based surveys of Steller sea lions (Eumetopias jubatus) conducted in Alaska in June-July 2013 through 2015, and an update on the status and trend of the western distinct population segment in Alaska. US Department of Commerce, NOAA Tech Memo NMFS-AFSC-321
Gelatt TS, Trites AW, Hastings KK, Jemison LA, Pitcher KW, O'Corry-Crowe G (2007) Population trends, diet, genetics, and observations of Steller sea lions in Glacier Bay National Park. In: Piatt JF, Gende SM (eds) Proc 4th Glacier Bay Sci Symp, October 26-28, 2004. US Geol Surv Sci Invest Rep 2007-5047, p 145-149

*Gende SM, Sigler MF (2006) Persistence of forage fish 'hot spots' and its association with foraging Steller sea lions (Eumetopias jubatus) in southeast Alaska. Deep Sea Res II 53:432-441

Hall DK, Benson CS, Field WO (1995) Changes of glaciers in Glacier Bay, Alaska using ground and satellite measurements. Phys Geogr 16:27-41

Hastings KK, Jemison LA (2016) Age-specific variation in timing of parturition in Steller sea lions at Forrester Island Complex, Alaska. Mar Mamm Sci 32:777-785

*Hastings KK, Gelatt TS, King JC (2009) Postbranding survival of Steller sea lion pups at Lowrie Island in Southeast Alaska. J Wildl Manag 73:1040-1051

*Hastings KK, Jemison LA, Gelatt TS, Laake JL and others (2011) Cohort effects and spatial variation in age-specific survival of Steller sea lions from southeastern Alaska. Ecosphere 2(10):111

* Heath RB, DeLong R, Jameson V, Bradley D, Spraker T (1997) Isoflurane anesthesia in free ranging sea lion pups. J Wildl Dis 33:206-210

Kerreman JK, Blundell GM, Ben-David M (2009) Evidence of bottom-up control of diet driven by top-down processes in a declining harbor seal Phoca vitulina richardsi population. Mar Ecol Prog Ser 374:287-300

* Hoffman JI, Matson CW, Amos W, Loughlin TR, Bickham JW (2006) Deep genetic subdivision within a continuously distributed and highly vagile marine mammal, the Steller's sea lion (Eumetopias jubatus). Mol Ecol 15:2821-2832

* Jemison LA, Pendleton GW, Fritz LW, Hastings KK, Maniscalco JM, Trites AW, Gelatt TS (2013) Inter-population movements of Steller sea lions in Alaska with implications for population separation. PLOS ONE 8:e70167

KKing JC, Gelatt TS, Pitcher KW, Pendleton GW (2007) A field-based method for estimating age in free-ranging Steller sea lions (Eumetopias jubatus) less than twentyfour months of age. Mar Mamm Sci 23:262-271

* Loughlin TR, Rugh DJ, Fiscus CH (1984) Northern sea lion distribution and abundance: 1956-80. J Wildl Manag 48: 729-740

Mackovjack J (2010) Navigating troubled waters: a history of commercial fishing in Glacier Bay, Alaska. US Department of the Interior, National Park Service, Glacier Bay National Park and Preserve, Gustavus, AK

Marston BH, Willson MF, Gende SM (2002) Predator aggregations during eulachon Thaleichthys pacificus spawning runs. Mar Ecol Prog Ser 231:229-236

Kathews EA, Pendleton GW (2006) Declines in harbor seal (Phoca vitulina) numbers in Glacier Bay National Park, Alaska, 1992-2002. Mar Mamm Sci 22:167-189

*Mathews EA, Womble JN, Pendleton GW, Jemison JA, Maniscalco JM, Streveler G (2011) Population growth and colonization of Steller sea lions in the Glacier Bay region of southeastern Alaska: 1970s-2009. Mar Mamm Sci 27:852-880

McGowan DW, Horne JK, Parker-Stetter SL (2016) Variability in species composition and distribution of forage fish in the Gulf of Alaska. Deep Sea Res II, doi:10.1016/j. dsr2.2016.11.019

* McLaughlin RL, Montgomerie RD (1989) Brood dispersal and multiple central place foraging by Lapland longspur parents. Behav Ecol Sociobiol 25:207-215 
Milner AM, Bailey RG (1989) Salmonid colonization of new streams in Glacier Bay National Park, Alaska. Aquacult Fish Manage 20:179-192

National Marine Fisheries Service (2013) Status review of the eastern distinct population segment of Steller sea lion (Eumetopias jubatus). National Marine Fisheries Service, Juneau, AK

National Research Council (2001) Marine protected areas: tools for sustaining ocean ecosystems. National Academy Press, Washington, DC

' O'Corry-Crowe G, Taylor BL, Gelatt T, Loughlin TR and others (2006) Demographic independence along ecosystem boundaries in Steller sea lions revealed by mtDNA analysis: implications for management of an endangered species. Can J Zool 84:1796-1809

* O'Corry-Crowe G, Gelatt T, Rea L, Bonin C, Rehberg M (2014) Crossing to safety: dispersal, colonization and mate choice in evolutionarily distinct populations of Steller sea lions, Eumetopias jubatus. Mol Ecol 23:5415-5434

* Pendleton GW, Hastings KK, Rea LD, Jemison LA, O'CorryCrowe GM, Beckmen KB (2016) Short-term survival of Steller sea lion (Eumetopias jubatus) pups: investigating the effect of health status on survival. Mar Mamm Sci 32: 931-944

Piatt JF, Wetzel J, Bell K, DeGange AR and others (2006) Predictable hotspots and foraging habitat of the endangered short-tailed albatross (Phoebastria albatrus) in the North Pacific: implications for conservation. Deep Sea Res II 53:387-398

Pitcher KW, Burkanov VN, Calkins DG, LeBoeuf BJ, Mamaev EG, Merrick RL, Pendleton GW (2001) Spatial and temporal variation in the timing of births of Steller sea lions. J Mammal 82:1047-1053

* Pitcher KW, Rehberg MJ, Pendleton GW, Raum-Suryan KL, Gelatt TS, Swain UG, Sigler MF (2005) Ontogeny of dive performance in pup and juvenile Steller sea lions in Alaska. Can J Zool 83:1214-1231

Pitcher KW, Olesiuk PF, Brown RF, Lowry MS and others (2007) Abundance and distribution of the eastern North Pacific Steller sea lion (Eumetopias jubatus) population. Fish Bull 107:102-115

R Core Team (2014) R: a language and environment for statistical computing. R Foundation for Statistical Computing, Vienna. www.R-project.org

Raum-Suryan KL, Pitcher KW, Calkins DG, Sease JL, Loughlin TR (2002) Dispersal, rookery fidelity, and metapopulation structure of Steller sea lions (Eumetopias jubatus) in an increasing and a decreasing population in Alaska. Mar Mamm Sci 18:746-764

Raum-Suryan KL, Pendleton GW, Pitcher KW, Gelatt TS (2004) Development of dispersal, movement patterns, and haul-out use by pup and juvenile Steller sea lions (Eumetopias jubatus) in Alaska. Mar Mamm Sci 20: 823-850

Rea LD, Fadely BS, Farley SD, Avery JP and others (2016) Comparing total body lipid content of young-of-the-year Steller sea lions among regions of contrasting population trends. Mar Mamm Sci 32:1200-1218

Rehberg MJ, Burns JM (2008) Differences in diving and swimming behavior of pup and juvenile Steller sea lions (Eumetopias jubatus) in Alaska. Can J Zool 86:539-553

Rehberg MJ, Gelatt TS (2003) Coastal bathymetry within the range of Steller sea lions in Alaska. Steller sea lion research initiative project 01-SSL-065, Alaska Department of Fish and Game, Anchorage, AK

Rehberg MJ, Andrews RD, Swain UG, Calkins DG (2009) Foraging behavior of adult female Steller sea lions dur- ing the breeding season in Southeast Alaska. Mar Mamm Sci 25:588-604

Robards MD, Drew GS, Piatt JF, Anson JM and others (2003) Ecology of selected marine communities in Glacier Bay: zooplankton, forage fish, seabirds and marine mammals. US Geological Survey, Alaska Science Center, Anchorage, AK

Saracco JF, Gabriele CM, Nielson JL (2013) Population dynamics and demography of humpback whales in Glacier Bay and Icy Strait, Alaska. Northwest Nat 94: 187-197

Sigler MF, Csepp DJ (2007) Seasonal abundance of two important forage species in the North Pacific Ocean, Pacific herring and walleye pollock. Fish Res 83:319-331

* Sigler MF, Tollit DJ, Vollenweider JJ, Thedinga JF and others (2009) Steller sea lion foraging response to seasonal changes in prey availability. Mar Ecol Prog Ser 388: 243-261

Trites AW, Porter BT (2002) Attendance patterns of Steller sea lions (Eumetopias jubatus) and their young during winter. J Zool 256:547-556

Trites AW, Calkins DG, Winship AJ (2007) Diets of Steller sea lions (Eumetopias jubatus) in Southeast Alaska, 1993-1999. Fish Bull 105:234-248

*Van Pelt TI, Piatt JF, Lance BK, Roby DD (1997) Proximate composition and energy density of some north Pacific forage fishes. Comp Biochem Physiol 118:1393-1398

Vollenweider JJ, Heintz RA, Schaufler L, Bradshaw R (2011) Seasonal cycles in whole-body proximate composition and energy content of forage fish vary with water depth. Mar Biol 158:413-427

Wildlife Computers (2009) DAP 2.0 software guide. Wildlife Computers, Redmond, WA

Williams PJ, Hooten MB, Womble JN, Esslinger GG, Bower MR, Hefley TJ (2017) An integrated data model to estimate spatio-temporal occupancy, abundance, and colonization dynamics. Ecology 98:328-336

Winship AJ, Trites AW (2003) Prey consumption of Steller sea lions (Eumetopias jubatus) off Alaska: How much prey do they require? Fish Bull 101:147-167

*Winship AJ, Trites AW, Rosen DAS (2002) A bioenergetic model for estimating the food requirements of Steller sea lions Eumetopias jubatus in Alaska, USA. Mar Ecol Prog Ser 229:291-312

*Womble JN, Gende SM (2013) Post-breeding season migrations of a top predator, the harbor seal, from a marine protected area in Alaska. PLOS ONE 8:e55386

*Womble JN, Sigler MF (2006) Seasonal availability of abundant, energy-rich prey influences the abundance and diet of a marine predator, the Steller sea lion Eumetopias jubatus. Mar Ecol Prog Ser 325:281-293

* Womble JN, Willson MF, Sigler MF, Kelly BP, VanBlaricom GR (2005) Distribution of Steller sea lions Eumetopias jubatus in relation to spring-spawning fish in SE Alaska. Mar Ecol Prog Ser 294:271-282

Womble JN, Sigler MF, Willson MF (2009) Linking seasonal distribution patterns with prey availability in a centralplace forager, the Steller sea lion. J Biogeogr 36:439-451

Womble JN, Pendleton GW, Mathews EA, Blundell GM, Bool NM, Gende SM (2010) Harbor seal (Phoca vitulina richardii) decline continues in the rapidly changing landscape of Glacier Bay National Park, Alaska 1992-2008. Mar Mamm Sci 26:686-697

Womble JN, Blundell GM, Gende SM, Horning M, Sigler MF, Csepp DJ (2014) Linking marine predator diving behavior to local prey fields in contrasting habitats in a subarctic glacial fjord. Mar Biol 161:1361-1374 